THE POLITICS OF DRUG CONTROL 


\section{The Politics of \\ Drug Control}

Mandy Bentham

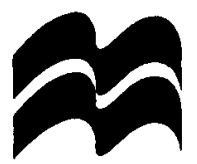


First published in Great Britain 1998 by

MACMILLAN PRESS LTD

Houndmills, Basingstoke, Hampshire RG21 6XS and London

Companies and representatives throughout the world

A catalogue record for this book is available from the British Library.

ISBN 978-1-349-40568-8 ISBN 978-0-230-37659-5 (eBook)

DOI $10.1057 / 9780230376595$

First published in the United States of America 1998 by

ST. MARTIN'S PRESS, INC.,

Scholarly and Reference Division,

175 Fifth Avenue, New York, N.Y. 10010

ISBN 978-0-312-21188-2

Library of Congress Cataloging-in-Publication Data

Bentham, Mandy.

The politics of drug control / Mandy Bentham.

p. $\mathrm{cm}$.

Includes bibliographical references and index.

ISBN 978-0-312-21188-2 (cloth)

1. Narcotics, Control of-International cooperation.

2. Narcotics, Control of - Govermment policy. 3. Drug abuse-

-Prevention-International cooperation. 4. Money laundering-

-Govemment policy-International cooperation. I. Title.

HV5801.B427 1997

$363.45-\mathrm{dc} 21$

97-40095

CIP

(c) Mandy Bentham 1998

Softcover reprint of the hardcover 1st edition 1998 978-0-333-72546-7

All rights reserved. No reproduction, copy or transmission of this publication may be made without written permission.

No paragraph of this publication may be reproduced, copied or transmitted save with written permission or in accordance with the provisions of the Copyright, Designs and Patents Act 1988, or under the terms of any licence permitting limited copying issued by the Copyright Licensing Agency, 90 Tottenham Court Road, London W IP 9HE.

Any person who does any unauthorised act in relation to this publication may be liable to criminal prosecution and civil claims for damages.

The author has asserted her right to be identified as the author of this work in accordance with the Copyright, Designs and Patents Act 1988.

This book is printed on paper suitable for recycling and made from fully managed and sustained forest sources.

$\begin{array}{llllllllll}10 & 9 & 8 & 7 & 6 & 5 & 4 & 3 & 2 & 1\end{array}$

$\begin{array}{llllllllll}07 & 06 & 05 & 04 & 03 & 02 & 01 & 00 & 99 & 98\end{array}$ 
To My Mother and Husband with Love and Thanks 


\section{Contents}

List of Figures $\quad \mathrm{x}$

Acknowledgements $\quad \mathrm{xi}$

List of Abbreviations xii

1 The Global Politics of Drug Control 1

Introduction 1

Interdependence: Rosenau's four characteristics 3

Issue-linkage 6

The challenge to Realism from interdependence 14

The Global Politics paradigm 15

The politics of semantics 17

The structure of the book 25

Conclusion $\quad 27$

2 The Scope and Nature of the Drug Phenomenon 28

Introduction 28

The nature of the drug phenomenon 31

The increase in drug trafficking $\quad 40$

Problems to control 44

Drug control and issue-politics $\quad 49$

The International Relations literature on issues $\quad 50$

Terminological confusion $\quad 52$

Issues and agenda-formation $\quad 54$

Conclusion $\quad 57$

3 A History of Drug Use: The Dynamics of Change 59

$\begin{array}{ll}\text { Introduction } & 59\end{array}$

The cultural tradition $\quad 60$

The dynamics of change $\quad 64$

The Eastern dimension and changing attitudes 71

Values and agenda-formation: From the value of power to the power of values $\quad 76$

$\begin{array}{ll}\text { The nature of values } & 80\end{array}$

Epistemic communities $\quad 85$

$\begin{array}{ll}\text { Conclusion } & 87\end{array}$ 
4 The United Nations and International Drug Control 89

$\begin{array}{ll}\text { Introduction } & 89\end{array}$

The League of Nations period $\quad 90$

The United Nations period $\quad 92$

Structure for UN drug control activities, pre-Special Session $\quad 94$

Drug control in the 1980s 101

$\begin{array}{ll}\text { The restructuring process } & 106\end{array}$

The United Nations International Drug Control $\begin{array}{ll}\text { Programme } & 107\end{array}$

The future role of the $\mathrm{UN}$ in international drug control 110

International collaboration and international regimes 113

$\begin{array}{ll}\text { Conclusion } & 117\end{array}$

5 Keep off the Grass: Drug Norms and International

Relations

$\begin{array}{ll}\text { Introduction } & 119\end{array}$

Issue-systems, norms and international regimes 121

$\begin{array}{ll}\text { The nature of norms } & 123\end{array}$

$\begin{array}{ll}\text { The role of norms } & 129\end{array}$

The norms of drug control 133

Conclusion 138

6 The International Money-Laundering Control Regime 140

Introduction $\quad 140$

The money-laundering issue $\quad 142$

The scale of the problem 144

Washing the money 145

International co-operation $\quad 154$

$\begin{array}{ll}\text { Norm emergence } & 160\end{array}$

The FATF: a money-laundering control regime $\quad 163$

$\begin{array}{ll}\text { Conclusion } & 166\end{array}$

7 International Regimes and Drug Control in the 1990s 167

$\begin{array}{ll}\text { Introduction } & 167\end{array}$

Regime creation $\quad 167$

The dynamics of change $\quad 172$

The role of norms $\quad 175$

Drug trafficking and money laundering: the focus of international attention $\quad 176$

Value dynamics and the drug legalisation debate $\quad 183$

$\begin{array}{ll}\text { Conclusion } & 188\end{array}$ 
Appendixes

A: List of Targets of the Comprehensive Multidisciplinary Outline of Future Activities in Drug Abuse Control adopted at the 1987 International Conference on Drug Abuse and Illicit Trafficking

B: Basle Committee on Banking Regulations and Supervisory Practices, December 1988. Statement on Prevention of Criminal Use of the Banking System for the Purpose of Money Laundering

Notes

Bibliography 


\section{List of Figures}

4.1 UN drug control, pre-Special Session 95

4.2 United Nations International Drug Control Programme 109

5.1 Regime creation $\quad 122$

$\begin{array}{ll}7.1 \text { Donnelly's regime classification } & 178\end{array}$ 


\section{Acknowledgements}

I would like to thank everyone who has helped and supported me throughout the research for this book. In particular, many thanks are owed to my PhD supervisor, Dr Peter Willetts, for his endless enthusiasm and encouragement. I would also like to thank my colleagues, David Humphreys, Peter Hough and Lewis Clifton of the Transgovernmental Relations Research Group at City University for their willingness to discuss and debate this work. 


\section{List of Abbreviations}

AIDS

$\mathrm{BCCI}$

BSA

BCP

CATF

$\mathrm{CCC}$

CIA

$\mathrm{CMO}$

CND

CORA

CTR

DEA

DIU

DND

DPF

DTOA

ECOSOC

EDU

EMNDP

FAO

FATF

FOPAC

GATT

HIV

HONLEA

ICDAIT

ICAO
Acquired Immune Deficiency Syndrome

Bank of Credit and Commerce International

Bank Secrecy Act 1971 (US)

Burmese Communist Party

Chemical Action Task Force of the Group of Seven

Customs Cooperation Council

Central Intelligence Agency

Comprehensive Multidisciplinary Outline of Future Activities in Drug Abuse Control (see Appendix A)

Commission on Narcotic Drugs of ECOSOC

Coordinamento Radicale Antiproibizionista

Currency Transaction Report

Drug Enforcement Administration (US)

Drugs Intelligence Unit of Europol

Division of Narcotic Drugs of the UN Secretariat

Drug Policy Foundation

Drug Trafficking Offences Act 1986 (UK)

Economic and Social Council of the United Nations

European Drugs Unit

European Movement for the Normalization of Drug Policy

Food and Agriculture Organization of the United Nations

Financial Action Task Force of the Group of Seven

Fonds provenant des activités criminelles

General Agreement on Tariffs and Trade

Human immune deficiency virus

Heads of National Drug Law Enforcement Agencies

UN Conference on Drug Abuse and Illicit Trafficking 1987

International Civil Aviation Organization 
ICPO/Interpol International Criminal Police Organization

ILO

IMO

INCB

MAG

MLAT

NATO

NORML

OECD

Pompidou Group

Swift

UNDCP

UNDP

UNFDAC

UNICEF

UNIDO

UNITAR

UPU

WFP

WHO
International Labour Organization

International Maritime Organization

International Narcotics Control Board (UN)

Mutual Assistance Group of the European Community

Mutual Legal Assistance Treaty

North Atlantic Treaty Organization

National Organisation for the Reform of Marijuana Laws

Organization for Economic Cooperation and Development

Co-operation Group to Combat Drug Abuse and Illicit Trafficking in Drugs

Society for Worldwide Interbank Financial Telecommunications

UN International Drug Control Programme

UN Development Programme

UN Fund for Drug Abuse Control

UN Children's Fund

UN Industrial Development Organization

UN Institute for Training and Research

Universal Postal Union

World Food Programme

World Health Organization (UN) 